\title{
Effects of Alkoxide Addition on the Electrochemical Deposition and Dissolution in Triglyme-based Solution Dissolving Magnesium Bis(trifluoromethanesulfonyl)amide
}

\author{
In-Tae Kim $^{1}$, Kazuhiro Yamabuki ${ }^{1}$, Masayuki Morita ${ }^{1}$, Hiromori Tsutsumi ${ }^{2}$, Nobuko \\ Yoshimoto $^{1, *}$ \\ ${ }^{1}$ Graduate School of Science and Engineering, Yamaguchi University \\ 2-16-1, Tokiwadai, Ube, 755-8611, Japan \\ ${ }^{2}$ Graduate School of Medicine, Yamaguchi University, 2-16-1, Tokiwadai, Ube, 755-8611, \\ Japan
}

*Corresponding author

Phone : $+81-836-85-9213$

Fax : +81-836-85-9201

Email: nobuko@yamaguchi-u.ac.jp 


\begin{abstract}
Electrochemical deposition and dissolution of magnesium $(\mathrm{Mg})$ has been examined in triethylene glycol dimethyl ether (triglyme, G3) dissolving magnesium bis(triflouromethanesulfonyl)amide, $\operatorname{Mg}(\mathrm{TFSA})_{2}$. The voltammetric current responses at platinum (Pt) electrode in the G3-based electrolytes revealed that the $\mathrm{Mg}$ deposition/dissolution process depends on the $\mathrm{Mg}$ species in the solution phase. The addition of alkoxides, $\operatorname{Mg}\left(\mathrm{OC}_{n} \mathrm{H}_{2 n+1}\right)_{2}$, was effective on the reversibility of the process in $\operatorname{Mg}(\mathrm{TFSA})_{2} / \mathrm{G} 3$. Higher anodic current corresponding to the electrochemical dissolution was observed in the electrolyte solution containing $\mathrm{Mg}\left(\mathrm{OC}_{2} \mathrm{H}_{5}\right)_{2}$ as the additive. The morphology of the $\mathrm{Mg}$ deposition at the Pt substrate also depended on the additive Mg-alkoxides. The resulting $\operatorname{Mg}(\mathrm{TFSA})_{2} / \mathrm{G} 3$ solutions containing Mg-alkoxides were found to be a possible electrolyte system for rechargeable $\mathrm{Mg}$ battery operating at ambient temperature.
\end{abstract}

Key words: Rechargeable magnesium magnesium bis(trifluoromethanesulfonyl)amide, triglyme, magnesium alkoxide 


\section{Introduction}

Rechargeable magnesium $(\mathrm{Mg})$ battery has widely attracted much attention as a possible candidate of so-called next generation batteries because of the merits on high volumetric capacity (3832 $\left.\mathrm{Ah} \mathrm{L}^{-1}\right)$, high specific capacity (2230 $\left.\mathrm{Ah} \mathrm{kg}^{-1}\right)$, low electrode potential (-2.356 $\mathrm{V}$ vs. SHE) of $\mathrm{Mg}$ metal as the negative electrode, and natural abundance of $\mathrm{Mg}$ resources. One of the key issues to realize a practical rechargeable $\mathrm{Mg}$ battery system is the sufficient rechargeability of $\mathrm{Mg}$ negative electrode in non-aqueous electrolyte systems. Unlike lithium (Li), Mg does not show good reversibility in non-aqueous electrolyte solutions dissolving such conventional $\mathrm{Mg}$ salts as $\mathrm{MgCl}_{2}, \mathrm{Mg}\left(\mathrm{ClO}_{4}\right)_{2}$ and $\mathrm{Mg}\left(\mathrm{CF}_{3} \mathrm{SO}_{3}\right)_{2}$, due to the formation of passivating layers on $\mathrm{Mg}$ surface [1-3].

Up to the present, it has been considered that the promising electrolyte systems should consist of tetrahydrofuran (THF) as solvent and organo-metal complexes as $\mathrm{Mg}$ sources for rechargeable Mg electrode [3-6]. The THF-based solution shows excellent cyclability, but THF has some drawbacks such as narrow electrochemical window (less electrochemical stability), corrosive nature to metal substrate and high volatility, and therefore, alternative organic solvents are still required to construct more stable and reliable electrolyte systems for rechargeable $\mathrm{Mg}$ batteries.

Recently, oligo(ethylene glycol) dimethyl ethers, so called glyme family, have been proposed for Li-ion battery system. In general, glymes consisting of oligo(ethylene oxide) units, $-\left(\mathrm{CH}_{2} \mathrm{CH}_{2} \mathrm{O}\right)_{\mathrm{n}^{-}}$, can interact with alkali metal cations of $\mathrm{Li}^{+}, \mathrm{Na}^{+}$etc. to form complexes in solution phases [7]. Watanabe et al. have reported the chemical structures of the complexes of Li salt in tetraglyme (G4) and pentaglyme (G5) by X-ray analysis and Raman spectroscopy [8]. They also proved that the glyme-based complexes can serve as liquid electrolytes in Li-battery system [7]. Since these glymes show higher boiling points and lower vapor pressure than THF, they are also attractive solvents for $\mathrm{Mg}$ batteries.

We have examined $\mathrm{Mg}$ salt-containing electrolytes with lower vapor pressure for rechargeable $\mathrm{Mg}$ electrode. Ionic liquid-based electrolyte, $\operatorname{Mg}(\mathrm{TFSA})_{2}$ dissolved in EMITFSA (EMI: 1-ethyl-3methylimidazolium, TFSA: bis(trifluoromethanesulfonyl)amide), and polymeric gel electrolyte containing $\mathrm{Mg}(\mathrm{TFSA})_{2}$ showed satisfactory high ionic 
conductivity and good thermal and electrochemical stability [9-12]. On the other hand, Abe et al. have investigated the $\mathrm{Mg}$ electrode behavior in 2-methytetrahydrofuran dissolving $\mathrm{MgBr}_{2}$ electrolyte $\left(\mathrm{MgBr}_{2} / 2-\mathrm{MeTHF}\right)[13,14]$. They found that the addition of $\mathrm{Mg}$-ethoxide, $\mathrm{Mg}\left(\mathrm{OC}_{2} \mathrm{H}_{5}\right)_{2}$, shows a drastic increase in the coulombic efficiency for $\mathrm{Mg}$ deposition and dissolution at elevated temperature at room temperature.

In the present work, we have examined an electrolyte system of $\operatorname{Mg}(\mathrm{TFSA})_{2}$ dissolved in triglyme $\left(\mathrm{G} 3: \mathrm{CH}_{3} \mathrm{O}\left(\mathrm{CH}_{2} \mathrm{CH}_{2} \mathrm{O}\right)_{3} \mathrm{CH}_{3}\right)$ whose vapor pressure is much lower than those of THF families. The effects of $\mathrm{Mg}$-alkoxides $\left(\mathrm{Mg}\left(\mathrm{OC}_{n} \mathrm{H}_{2 n+1}\right)_{2}\right)$ addition were investigated for electrochemical deposition and dissolution of $\mathrm{Mg}$ in $\mathrm{Mg}(\mathrm{TFSA})_{2} / \mathrm{G} 3$. We used methoxide, $\mathrm{Mg}\left(\mathrm{OCH}_{3}\right)_{2}$, and ethoxide, $\mathrm{Mg}\left(\mathrm{OC}_{2} \mathrm{H}_{5}\right)_{2}$, as the additive components, and focused on the changes in the voltammetric responses for $\mathrm{Mg}$ deposition/dissolution from/to the solutions with and without the additives. Influences of the additives on the morphology of the deposit were also investigated under ambient temperature conditions.

\section{Experimental}

\subsection{Preparation of the electrolyte solution}

High purity $\operatorname{Mg}(\text { TFSA })_{2}(<99.9 \%$, Morita chemical $)$ was used as the electrolyte salt for $\mathrm{Mg}$ deposition/dissolution, which was dried under a vacuum at $120{ }^{\circ} \mathrm{C}$ for $48 \mathrm{~h}$ and stored in a glove box filled with dry $\operatorname{Ar}$ (the dew point $<-90{ }^{\circ} \mathrm{C}$ ) at ambient temperature. The glyme G3 (Alfa Aeser, $99.0 \%$ ) was treated to remove dissolved oxygen and water by molecular sieves, until the residual water contents in the solvents to be less than $100 \mathrm{ppm}$. The $\mathrm{Mg}$ salt was dissolved in $\mathrm{G} 3$ solvent to make $0.7 \mathrm{~mol} \mathrm{dm}^{-3}(\mathrm{M})$ solution, $\operatorname{Mg}(\mathrm{TFSA})_{2} / \mathrm{G} 3$. The alkoxides, $\mathrm{Mg}\left(\mathrm{OCH}_{3}\right)_{2}$ and $\mathrm{Mg}\left(\mathrm{OC}_{2} \mathrm{H}_{5}\right)_{2}(<99.3 \%$, Kojundo Chemical $)$, were used as-received for the electrolyte additives. For comparison, solutions using G3 solvent without $\operatorname{Mg}(\mathrm{TFSA})_{2}$ were also examined, in which DEMETFSA (Kanto Chemical, DEME: $N, N$-diethyl- $N$-methyl$N$-(2-methoxyethyl)ammonium) was used as the supporting electrolyte.

\subsection{Electrochemical measurements}

The ionic conductivities of electrolyte solutions were measured by ac impedance method $\left(10^{5} \mathrm{~Hz} \sim 10 \mathrm{~Hz}, 10 \mathrm{mV}_{\mathrm{p}-\mathrm{p}}\right)$ using a frequency response analyzer with electrochemical 
measurement equipment (Hokuto denko, HZ-7000). The electrochemical deposition and dissolution processes of $\mathrm{Mg}$ in the electrolyte solution were investigated by cyclic voltammetry (CV) using a potentiostat/galvanostat (Bio-logic science instrument, VSP-300) at ambient temperature ( $298 \pm 3 \mathrm{~K})$. A conventional 3-electrode beaker cell was using a $\mathrm{Pt}$ sheet $\left(0.5 \mathrm{~cm}^{2}\right)$ as the working electrode, and the quasi-reference and counter electrode were using $\mathrm{Mg}$ rod and Pt sheet with a large surface area $\left(3.0 \mathrm{~cm}^{2}\right)$, respectively. The potential scanning range and rate in $\mathrm{CV}$ were -2.0 to $2.0 \mathrm{~V}$ (vs. $\mathrm{Mg}$ ) and $20 \mathrm{mV} \mathrm{s}^{-1}$, respectively.

A cathodic deposition of $\mathrm{Mg}$ was also conducted under a potentiostatic condition at $-2.0 \mathrm{~V}$ vs. $\mathrm{Mg} / \mathrm{Mg}^{2+}$ for $10 \mathrm{~min}$. The resulting deposit was characterized by X-ray diffraction and scanning electron microscopy (SEM) observation (Keyence, VE-8800).

\section{Results and Discussion}

\subsection{Electrochemical behavior of the additives}

The temperature dependence of the ionic conductivities in $\mathrm{Mg}(\mathrm{TFSA})_{2} / \mathrm{G} 3$ electrolyte with or without Mg-alkoxides measured by the ac impedance method is shown in Fig. 1. The ionic conductivity of $\mathrm{Mg}(\mathrm{TFSA})_{2} / \mathrm{G} 3$ is not significantly changed by the addition of Mg-alkoxides.

In order to understand basic electrochemical behavior of the Mg-alkoxides, $\mathrm{CV}$ experiments was carried out using the G3-based solutions without $\operatorname{Mg}$ (TFSA). Figure 2 shows $\mathrm{CV}$ responses of Pt electrode in the $\mathrm{G} 3$ solutions dissolving (a) $0.35 \mathrm{M} \mathrm{Mg}\left(\mathrm{OCH}_{3}\right)_{2}$, (b) $0.1 \mathrm{M}$ DEMETFSA, (c) 0.1 M DEMETFSA + 0.35 $\mathrm{M} \mathrm{Mg}\left(\mathrm{OCH}_{3}\right)_{2}$ and (d) $0.7 \mathrm{M} \mathrm{Mg}(\mathrm{TFSA})_{2}$. In the solution of $0.7 \mathrm{M} \mathrm{Mg}(\mathrm{TFSA})_{2} / \mathrm{G} 3$, the cathodic current increase at $-0.5 \mathrm{~V}$ or below and the anodic current peak at $+1.5 \mathrm{~V}$ were observed, which would mainly correspond to the electrochemical deposition and dissolution of $\mathrm{Mg}$, respectively. Despite of lower ratio in the anodic current to the cathodic one, the $\mathrm{CV}$ response in $\mathrm{Mg}(\mathrm{TFSA})_{2} / \mathrm{G} 3$ strongly suggests that the electrochemical deposition and dissolution of $\mathrm{Mg}$ should occur on Pt electrode in this electrolyte system at ambient temperature. Similar results have been recently reported by Orikasa et al. [15], in which the process was shown at higher temperature (373K) with rather high overpotential. By comparing the current responses of curves a and $\mathrm{c}$ in Fig. 2, the cathodic deposition and anodic dissolution of $\mathrm{Mg}$ can proceed in DEMETFSA/G3 containing 
$\mathrm{Mg}\left(\mathrm{OCH}_{3}\right)_{2}$. Much lower current response observed in $\mathrm{Mg}\left(\mathrm{OCH}_{3}\right)_{2} / \mathrm{G} 3$ would indicate that sufficient concentration of ionic species is required for the deposition/dissolution processes. We observed significant difference in the onset potentials for $\mathrm{Mg}$ deposition and dissolution (the potentials where the anodic and cathodic currents respectively increase) between curves c and d. Differences in the electrolyte properties, such as ionic species, ionic strength and conductivity, are probably responsible for these differences although their details are still unknown at the present stage.

\subsection{Influences of the additives in the electrolyte solution}

Figure 3 shows the cyclic voltammograms of $\mathrm{Pt}$ in the $\operatorname{Mg}(\mathrm{TFSA})_{2} / \mathrm{G} 3$ solution with Mg-alkoxides additives. Here, the molar ratio of the additives to $\operatorname{Mg}(\mathrm{TFSA})_{2}$ was 1:5 (the absolute molar concentration of the additives was $0.14 \mathrm{M}$ ). The anodic current was slightly increased with the addition of $\mathrm{Mg}$-methoxide, $\mathrm{Mg}\left(\mathrm{OCH}_{3}\right)_{2}$. When $\mathrm{Mg}$-ethoxide, $\mathrm{Mg}\left(\mathrm{OC}_{2} \mathrm{H}_{5}\right)_{2}$, was added, both the cathodic and anodic currents increased significantly. The onset potentials for both cathodic deposition and the anodic dissolution shifted to the direction of lower overpotential. These results prove that the alkoxide in the solution can enhance the electrochemical $\mathrm{Mg}$ deposition/dissolution processes in $\mathrm{Mg}(\mathrm{TFSA})_{2} / \mathrm{G} 3$. Also, smaller anodic current peak or shoulder was observed at around $0.3 \mathrm{~V}$ in the solutions containing the alkoxides, which would correspond to the current response in DEMETFSA+Mg( $\left(\mathrm{OCH}_{3}\right)_{2} / \mathrm{G} 3$, shown in Fig. 2d. These CV responses suggest that the anodic process consists of at least two steps in the $\operatorname{Mg}(\mathrm{TFSA})_{2} / \mathrm{G} 3$ system containing alkoxides.

Influences of the $\mathrm{Mg}$ alkoxides on the morphology of $\mathrm{Mg}$ deposition were investigated by SEM observation. The cathodic deposition of $\mathrm{Mg}$ was carried out on Pt sheet substrate at constant potential $\left(-2.0 \mathrm{~V}\right.$ vs. $\left.\mathrm{Mg} / \mathrm{Mg}^{2+}\right)$ for $10 \mathrm{~min}$ in $0.7 \mathrm{M} \mathrm{Mg}(\mathrm{TFSA})_{2} / \mathrm{G} 3$ with or without the additives. Figure 4 shows SEM images for the deposits obtained from the electrolyte (a) without additives and (b) with $0.14 \mathrm{M} \mathrm{Mg}\left(\mathrm{OCH}_{3}\right)_{2}$. It was confirmed that the both deposits are Mg metal with hexagonal crystalline by XRD measurements. The SEM images also reveal that the deposits consist of spherical particles with micrometer-order sizes. From the solution without additives, the deposit tends to form rather smooth surface spheres (Fig. 4a). This observation is consistent with that recently reported by other research groups using similar 
glyme-based electrolytes $[15,16]$. On the other hand, the deposition from the electrolyte containing $\mathrm{Mg}\left(\mathrm{OCH}_{3}\right)_{2}$ gave aggregation of smaller sizes of sphere and flake (Fig. 4b). The difference in the current response for anodic dissolution given in Fig. 3 would reflect such differences in the surface morphology of the deposit as shown in Fig. 4. Thus, the addition of alkoxides would control the morphology of the $\mathrm{Mg}$ deposition, and hence affect the rate of anodic dissolution in the glyme-based electrolyte solution, although details of the actual mechanism of the additive's function are still unclear. Variations in the ionic structure and physicochemical properties that could influence the electrochemistry of $\mathrm{Mg}$ in glyme-based electrolyte systems are now under investigation.

\section{Conclusion}

We have investigated the electrochemical deposition and dissolution of $\mathrm{Mg}$ in triglyme (G3) containing $\mathrm{Mg}(\mathrm{TFSA})_{2}$ with alkoxides, $\mathrm{Mg}\left(\mathrm{OC}_{n} \mathrm{H}_{2 n+1}\right)_{2}$, as the additive components. The process in the $\operatorname{Mg}(\mathrm{TFSA})_{2} / \mathrm{G} 3$ system was enhanced significantly by the alkoxide addition even at ambient temperature (around $298 \mathrm{~K}$ ). Changes in the surface morphology of the deposit would lead to the shift of the onset potential (decrease in the overpotentials) for both the cathodic deposition and anodic dissolution. The resulting $\operatorname{Mg}(\mathrm{TFSA})_{2} / \mathrm{G} 3$ containing $\mathrm{Mg}\left(\mathrm{OC}_{n} \mathrm{H}_{2 n+1}\right)_{2}$ additives can be used as an electrolyte system that works for reversible $\mathrm{Mg}$ metal electrode at ambient temperature.

\section{Acknowledgments}

This work was partly supported by the Advanced Low Carbon Technology Research and Development Program (ALCA, Contract No. 11102784) from Japan Science and Technology Agency (JST).

\section{References}

[1] T. D. Gregory, R. J. Hoffman, R. C. Wintertem, J. Electrochem. Soc., 1990, 137, 775-780.

[2] P. Saha, M. K. Datta, O. I. Velikokhatnyi, A. Manivannan, D. Alman, P. N. Kurnta, Prog. Mater. Sci., 2014, 66, 1-86. 
[3] Z. Lu, A. Schechter, M. Moshkovich, D. Aurbach, J. Electroanal. Chem. 1999, 466, 203-217.

[4] D. Aurbach, Z. Lu, A. Schechter, Y. Gofer, H. Gizbar, R. Turgeman, Y. Cohen, M. Moshkovich, E. Levi, Nature, 2000, 407, 724-727.

[5] D. Aurbach, H. Gizbar, A. Schechter, O. Chusid, H. E. Gottlieb, Y. Gofer, I. Goldberg, J. Electrochem. Soc., 2002, 149(2), A115-A121.

[6] Y.Viestfrid, M.D. Levi, Y. Gofer, D. Aurbach, J. Electroanal. Chem, 2005, 576, 183.

[7] K. Yoshida, M. Tsuchiya, N. Tachikawa, K. Dokko, M. Watanabe, J. Electrochem. Soc., 2012, 159(7), A1005-A1012.

[8] T. Mandai, R. Nozawa, S. Tsuzuki, K. Yoshida, K. Ueno, K. Dokko, M. Watanabe, J. Phys. Chem. B, 2013, 117, 15072-15085.

[9] N. Yoshimoto, Y. Tomonaga, M. Ishikawa, M. Morita, Electrochim. Acta, 2001, 46, $1195-1200$.

[10] N. Yoshimoto, S. Yakushiji, M. Ishikawa, M. Morita, Electrochim. Acta, 2003, 48, $2317-2322$.

[11] N. Yoshimoto, M. Matsumoto, M. Egashira, M. Mortia, J. Power Sources 195 (2010) 2096-2098.

[12] T. Kakibe, N. Yoshimoto, M. Egashira, M. Mortia, Electrochem. Commun. 12 (2010) $1630-1633$

[13] K. Asaka, K. Miyazaki, T. Fukutsuka, T. Abe, K. Nishio, Y. Uchimoto, PRiME 2012 abstract (2012).

[14] T. Abe, K. Miyazaki, T. Fukutsuka, K. Nishio, Y. Uchimoto, $224^{\text {th }}$ ECS meeting abstract (2013).

[15] Y. Orikasa, T. Masese, Y. Koyama, T. Mori, M. Hattori, K. Yamamoto, T. Okado, Z.-D. Huang, T. Minato, C. Tassel, J. Kim, Y. Kobayashi, T. Abe, H. Kageyama, Y. Uchimoto, Sci. Reports, 2014, 4, 5622-5627.

[16] S.-Y. Ha, Y.-W. Lee, S. W. Woo, B. Koo, J.-S. Kim, J. Cho, K. T. Lee, N.-S. Choi, Appl. Mater. Interfaces, 2014, 6, 4063-4073. 


\section{Figure captions}

Fig. 1 Temperature dependence of ionic conductivities of G3 solutions containing ( $\mathbf{\square}$ ) $0.7 \mathrm{M}$ $\operatorname{Mg}(\text { TFSA })_{2}$, (०) $0.7 \mathrm{M} \mathrm{Mg}(\text { TFSA })_{2}+0.14 \mathrm{M} \mathrm{Mg}\left(\mathrm{OCH}_{3}\right)_{2}$ and ( $\left.\mathbf{\Delta}\right) 0.7 \mathrm{M} \mathrm{Mg}(\mathrm{TFSA})_{2}$ $+0.14 \mathrm{M} \mathrm{Mg}\left(\mathrm{OC}_{2} \mathrm{H}_{5}\right)_{2}$.

Fig. 2 Cyclic voltammograms of Pt electrode in G3 solutions containing (a) $0.35 \mathrm{M}$ $\mathrm{Mg}\left(\mathrm{OCH}_{3}\right)_{2}$, (b) 0.1 M DEMETFSA, (c) 0.1 M DEMETFSA + 0.35 M Mg(OCH 3$)_{2}$ and (d) $0.7 \mathrm{M} \mathrm{Mg}(\mathrm{TFSA})_{2}$.

Fig. 3 Cyclic voltammograms of Pt electrode in G3 solutions containing (a) $0.7 \mathrm{M}$ $\operatorname{Mg}(\text { TFSA })_{2}$, (b) $0.7 \mathrm{M} \mathrm{Mg}(\mathrm{TFSA})_{2}+0.14 \mathrm{M} \mathrm{Mg}\left(\mathrm{OCH}_{3}\right)_{2}$ and (c) $0.7 \mathrm{M} \mathrm{Mg}(\mathrm{TFSA})_{2}$ $+0.14 \mathrm{M} \mathrm{Mg}\left(\mathrm{OC}_{2} \mathrm{H}_{5}\right)_{2}$.

Fig. 4 SEM images of Mg deposited on Pt substrate electrode after cathodic deposition at $-2.0 \mathrm{~V}$ (vs. $\mathrm{Mg} / \mathrm{Mg}^{2+}$ ) for $10 \mathrm{~min}$ in (a) $0.7 \mathrm{M} \mathrm{Mg}(\mathrm{TFSA})_{2} / \mathrm{G} 3$ and (b) $0.7 \mathrm{M}$ $\operatorname{Mg}(\mathrm{TFSA})_{2}+0.14 \mathrm{M} \mathrm{Mg}\left(\mathrm{OCH}_{3}\right)_{2} / \mathrm{G} 3$. 


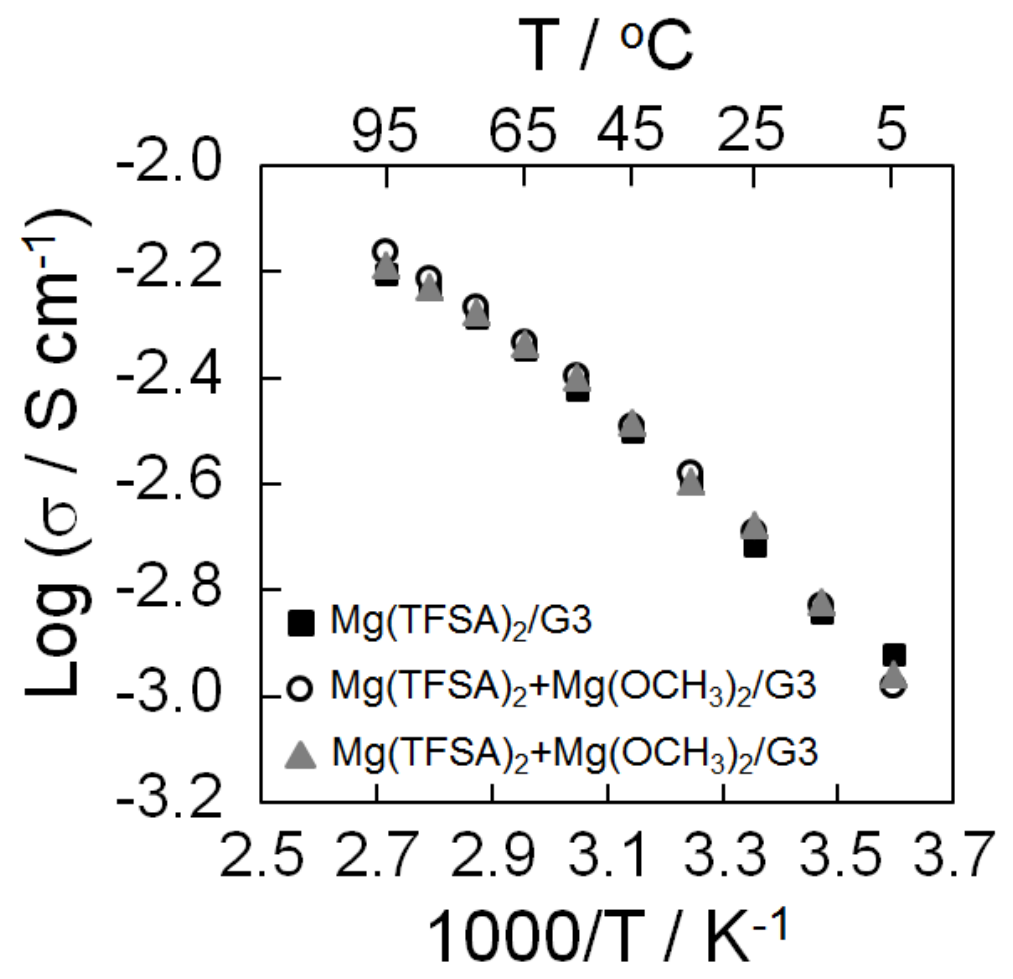

Fig. 1 (Kim, et al.) 


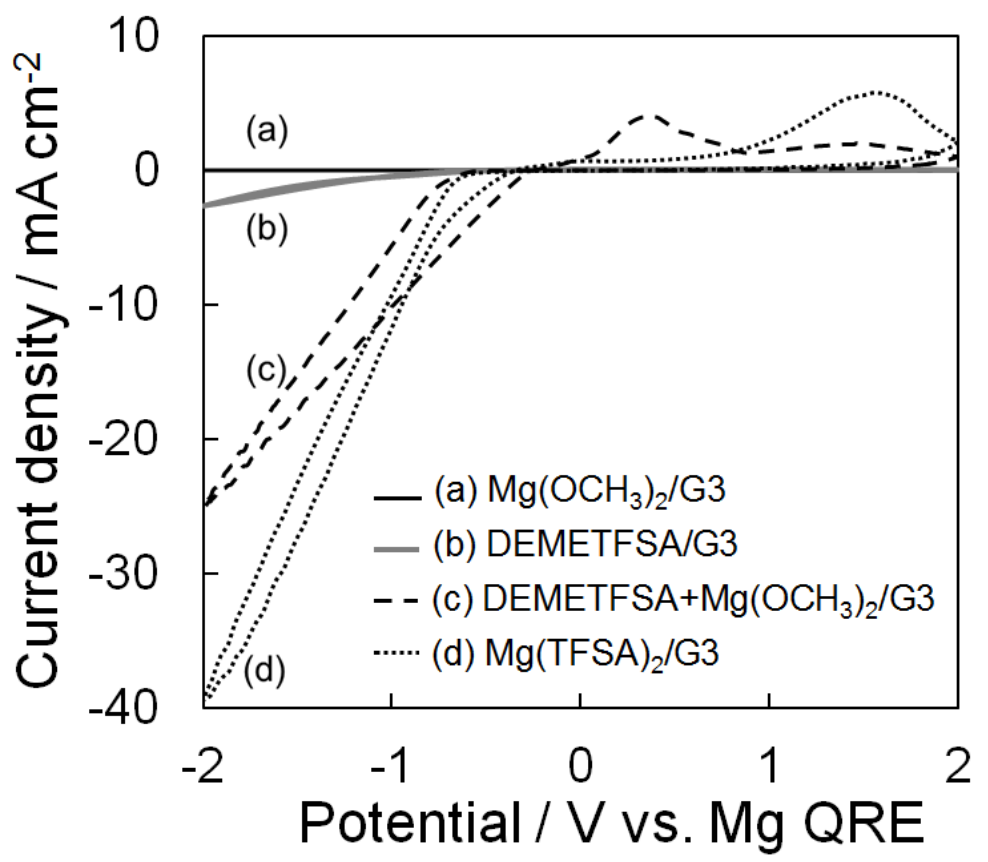

Fig. 2 (Kim, et al.) 


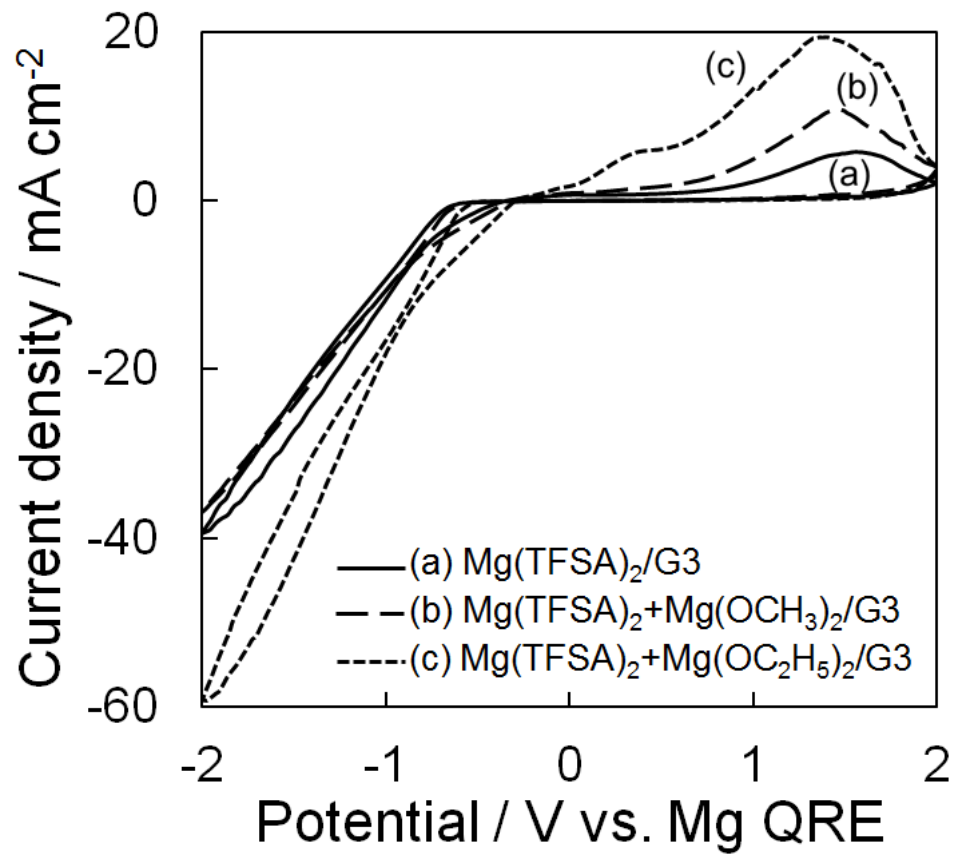

Fig. 3 (Kim, et al.) 

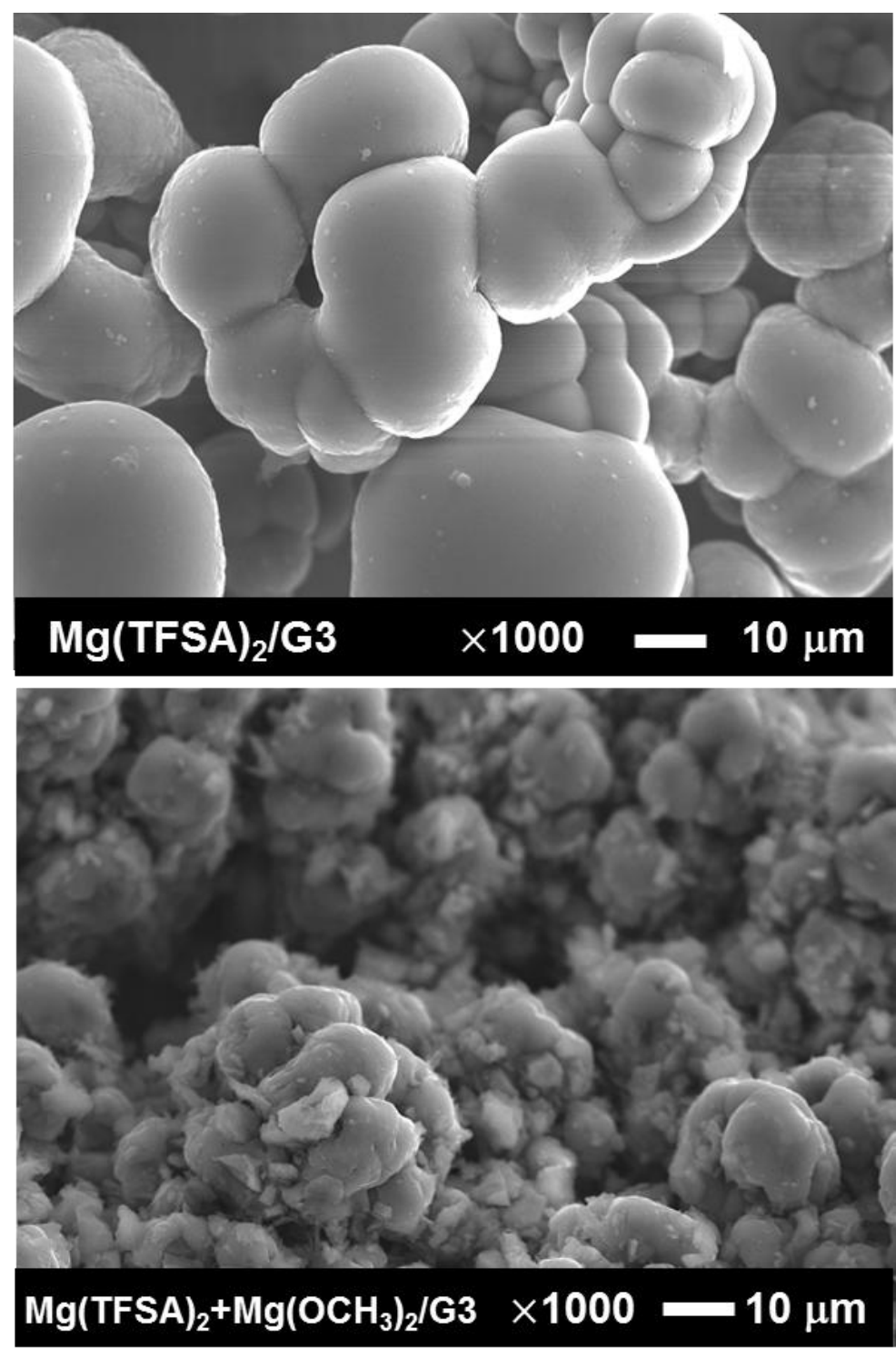

Fig. 4 (Kim, et al.) 